УДК 634.8

DOI: 10.30679 / 2219-5335-2018-2-50-40-55

ПРОГНОЗИРОВАНИЕ УРОЖАЯ ТЕХ-
НИЧЕСКИХ СОРТОВ
ВИНОГРАДА В ПРЕДГОРНОЙ ЗОНЕ
ВИНОГРАДАРСТВА ЮГА РОССИИ
НА ОСНОВЕ ИЗУЧЕНИЯ
ПЛОДОНОСНОСТИ ГЛАЗКОВ
И ВЕГЕТИРУЮЩИХ
ПОБЕГОВ

Матузок Николай Васильевич

д-р с.-х. наук, профессор

Трошин Леонид Петрович

д-р биол. наук, профессор

заведующий кафедрой виноградарства

Радчевский Петр Пантелеевич

канд. с.-х. наук, профессор

Кравченко Роман Викторович

д-р с.-х. наук, профессор

Федеральное государственное

бюджетное образовательное учреждение

высшего образования

«Кубанский государственный

аграрный университет»,

Краснодар, Россия

Цель исследований - дать сравнительную агробиологическую и хозяйственную оценку некоторым техническим сортам винограда в условиях Крымского района Краснодарского края при системе ведения и формирования кустов по типу Гюйо. На основе изучения степени закладки эмбриональных соцветий в почках зимующих глазков установить оптимальную длину обрезки плодовых стрелок для получения более высокого урожая винограда хорошего качества. Объекты исследования - кусты винограда 6 технических сортов западно-европейского происхождения, из которых 3 сорта с белой окраской ягод - Рислинг, Совиньон,

Шардоне и 3 сорта с темной окраской ягод
UDC 634.8

DOI: 10.30679 / 2219-5335-2018-2-50-40-55

HARVEST PREDICTION

OF TECHNICAL GRAPE VARIETIES

IN THE FOOTHILL ZONE

OF VITICULTURE IN THE SOUTH

OF RUSSIA ON THE BASIS

OF FRUITFULNESS STUDYING

OF BUDS AND VEGETATIVE

SHOOTS

Matuzok Nikolai Vasilyevich

Dr. Sci. Agr., Professor

Troshin Leonid Petrovich

Dr. Biol. Sci., Professor

Head of the Faculty of Viticulture

Radchevsky Piotr Panteleevich

Cand. Agr. Sci., Professor

Kravchenko Roman Viktorovich

Dr. Sci. Agr., Professor

Federal State

Budgetary Educational

Institution of Higher

Education "Kuban State

Agrarian University",

Krasnodar, Russia

The aim of the research is to give a comparative agrobiological and economic assessment to some technical grapes varieties in the conditions of the Krymsk district of Krasnodar Region under the system of bushes forming of the Guyot type.

On the basis of studying of the degree of embryonic inflorescence in the wintering buds, the optimal length of the fruit shooters pruning to obtain a higher grapes yield of good quality. The objects of the study were grapes bushes of 6 technical varieties of Western European origin, of which 3 varieties with white berries - Riesling, Sauvignon, Chardonnay 
- Каберне-Совиньон, Мерло и Пино нуар. В данной работе представлено прогнозирование урожая винограда и дана сравнительная агробиологическая и хозяйственная оценка изучаемых сортов в предгорной зоне виноградарства юга России. Определены важные биологические показатели сортов: коэффициенты плодоношения, плодоносности и продуктивности центральных почек. Это позволило установить оптимальную нагрузку кустов глазками и побегами. Более высокая урожайность отмечена на участке сорта винограда Мерло, где она составила 6,53 т/га. В условиях предгорной зоны Краснодарского края технические сорта с темной окраской ягоды накопили более высокое количество сахаров. По содержанию титруемых кислот у группы сортов с белой окраской ягод более высокие показатели были у Шардоне - 10,4 г/дм3. В группе темноокрашенных сортов содержание органических кислот не превышало 6,6 г/дм3. Более низкая себестоимость продукции винограда оказалась у сортов Шардоне и Мерло, соответственно 15,6 тыс. руб./т и 14,9 тыс. руб./т.

Ключевые слова: ПРОГНОЗИРОВАНИЕ УРОЖАЯ ВИНОГРАДА, СОРТ, КАЧЕСТВО, КОЭФФИЦИЕНТЫ ПЛОДОНОШЕНИЯ, ПЛОДОНОСНОСТИ И ПРОДУКТИВНОСТИ ГЛАЗКОВ, ЭФФЕКТИВНОСТЬ and 3 varieties with dark berries Cabernet Sauvignon, Merlot and Pinot Noir. In this paper, the prediction of the vine harvest is presented and a comparative agrobiological and economic evaluation of these grape varieties in the foothill zone of viticulture in the South of Russia is given. Important biological indicators of the studied varieties were determined: the coefficients of fruiting, fertility and productivity of the central buds. This allowed to establish the optimal load of bushes with buds and shoots.

Higher yields were recorded at the Merlot plot, where it was $6.53 \mathrm{t} / \mathrm{ha}$. In the foothill of the Krasnodar Region, the technical varieties with dark berries have accumulated a higher amount of sugars. The content of titrated acids in a group of varieties with white berries was higher in Chardonnay $-10.4 \mathrm{~g} / \mathrm{dm}^{3}$. In the group of dark-colored varieties, the content of organic acids did not exceed $6.6 \mathrm{~g} / \mathrm{dm}^{3}$. The lower cost price of grapes was found in the varieties of Chardonnay and Merlot, respectively, 15.6 thousand rubles per ton and 14.9 thousand rubles per ton.

Key words: PREDICTION OF GRAPE HARVEST, VARIETY, QUALITY, COEFFICIENTS OF FRUITAGE, FRUITFULNESS AND PRODUCTIVITY OF BUDS, EFFICIENCY

Введение. В интенсификации отрасли виноградарства совершенствованию подбора сортимента принадлежит ведущее место. Сорт определяет направление использования виноградной продукции и играет ведущую роль в улучшении ее качества [1-5]. Основу сортимента составляют классические технические сорта, из которых производят шампанские виноматериалы, высококачественные столовые, десертные и марочные вина. Успешное ведение отрасли виноградарства может быть достигнуто при 
Плодоводство и виноградарство Юга России № 50(02), 2018 г.

тщательном изучении биологических особенностей роста и развития виноградного растения. По данным ряда авторов $[6,7,8]$, особое внимание следует уделять формированию генеративных органов, которые в конечном цикле своего развития формируют гроздь.

Существенным фактором постоянного поиска перспективных сортов винограда является учет конъюнктуры рынка. Именно рынок диктует, каким должен быть конечный продукт, а значит и сорт винограда, из которого будет произведен виноматериал.

В литературных источниках недостаточно информации по изучению биологических, хозяйственных признаков и особенностей формирования эмбриональных (зачаточных соцветий) в почках глазков у сортов винограда западно-европейского происхождения в условиях Крымского района. Более полное изучение данного вопроса будет способствовать повышению продуктивности виноградных насаждений. С этой целью в ООО «Новокрымское» Крымского района Краснодарского края были приобретены саженцы одномерных клонов винограда, гарантирующих при соблюдении технологии достоверность их качества.

Цель исследований - дать сравнительную агробиологическую и хозяйственную оценку техническим сортам винограда в условиях Крымского района при системе ведения по типу Гюйо. На основе изучения степени закладки эмбриональных (зачаточных) соцветий в почках зимующих глазков установить оптимальную длину обрезки плодовых стрелок для получения более высокого урожая винограда хорошего качества.

\section{Задачи исследований:}

- изучить плодоносность глазков по длине однолетнего вызревшего плодового побега у исследуемых технических сортов винограда;

- дать сравнительную оценку показателям плодоношения и плодоносности вегетирующих побегов;

- определить по каждому сорту урожай винограда и его качество;

- дать экономическую оценку изучаемым сортам винограда при воз- 
делывании и формировании кустов по типу Гюйо в условиях Крымского района Краснодарского края.

Объекты и методы исследований. Исследования, в соответствии с поставленными задачами, были проведены в ООО «Новокрымское» Крымского района Краснодарского края в 2014-2016 гг.

В 2014 году погодные условия сложились вполне благоприятно для роста, развития и плодоношения винограда. Обилие тепла и света при хорошем и удовлетворительном водообеспечении создали условия для получения качественного урожая. Средняя температура воздуха в 2014 г. составила $14,2{ }^{\circ} \mathrm{C}$. Минимальная температура была зафиксирована в январе и составила минус $22,6{ }^{\circ} \mathrm{C}$. Максимальная температура воздуха наблюдалась в июле $-34,4{ }^{\circ} \mathrm{C}$. За 2014 год атмосферных осадков выпало 616 мм.

В 2015 году агрометеорологические условия для формирования урожая винограда также складывались благоприятно и отличались незначительно от условий 2014 года. Средняя температура воздуха $-12,2{ }^{\circ} \mathrm{C}$, минимальная была зафиксирована в декабре - минус $18,7^{\circ} \mathrm{C}$. Максимальная температура воздуха составила $34,1{ }^{\circ} \mathrm{C}$, в июле. В 2015 году выпало 581,6 мм атмосферных осадков.

В 2016 году агрометеорологические условия для формирования урожая винограда складывались, как и в предыдущие два года, вполне благоприятно. Средняя температура воздуха $-12,0{ }^{\circ} \mathrm{C}$, минимальная была зафиксирована в январе (минус $16,7^{\circ} \mathrm{C}$ ). Максимальная температура (в июле) составила $+35,1^{\circ} \mathrm{C}$. За 2016 год выпало 474,8 мм атмосферных осадков.

Объектами исследования являлись кусты винограда 7-летнего возраста шести технических сортов группы западно-европейского происхождения, из которых три сорта были с белой окраской ягод Рислинг, Совиньон, Шардоне и три сорта винограда с темной окраской ягод - Каберне-Совиньон, Мерло и Пино нуар. 
Плодоводство и виноградарство Юга России № 50(02), 2018 г.

Рислинг - технический сорт винограда, относится к экологогеографической группе западно-европейских сортов (рис. 1). Средняя масса грозди 80-100 г. Кусты сильнорослые. Плодоносных побегов в среднем $80 \ldots 87 \%$. Среднее количество гроздей на развившемся побеге 1,6 ; на плодоносном - 2,0. Сорт неустойчив к оидиуму, сильно восприимчив к серой гнили ягод, милдью поражается в меньшей степени, чем другие сорта. Проявляет склонность к осыпанию цветков, завязи и горошению ягод.

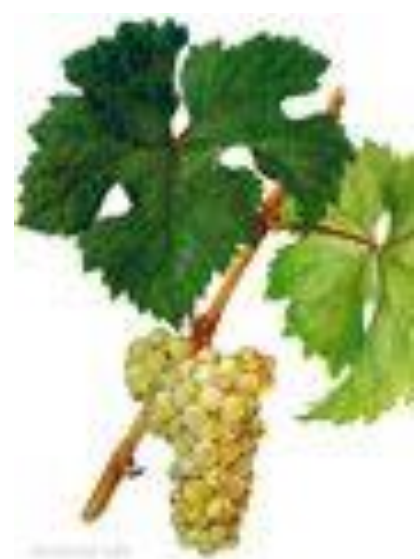

Рис. 1. Ампелоснимок сорта Рислинг

Шардоне - французский сорт винограда. Относится к сортам среднего срока созревания, грозди средние или мелкие (80-100 г), цилиндрические или конические. Ягоды средние или мелкие, округлые, иногда овальные, зеленовато-белые с золотистым оттенком (рис. 2).

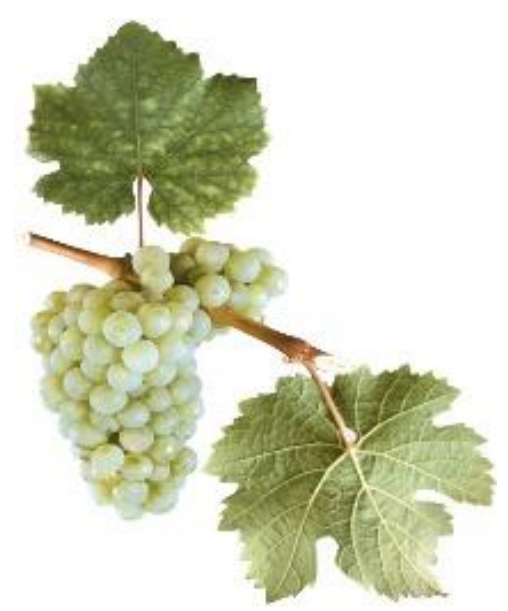

Рис. 2. Ампелоснимок сорта Шардоне 
Процент плодоносных побегов 60. Коэффициент плодоношения 1,11,2; плодоносности - 1,4-1,8. Урожайность невысокая. Сахаристость сока ягод 17-23 г/100 см ${ }^{3}$ при титруемой кислотности 6-11. Морозоустойчивость, зимостойкость и засухоустойчивость несколько выше, чем у многих европейских сортов. Сорт неустойчив к грибным болезням.

Совиньон бельй - французский технический сорт винограда среднего срока созревания. Средняя масса грозди 80-120 г. Ягода мелкая или средней величины. Мякоть сочная, гармоничного вкуса, со своеобразным ароматом и привкусом паслена. Кусты среднерослые. Плодоносных побегов 80 \%, коэффициент плодоношения побега 0,6; коэффициент плодоносности 1-1,2. Сорт поражается оидиумом и серой гнилью, сравнительно устойчив к милдью (рис. 3).

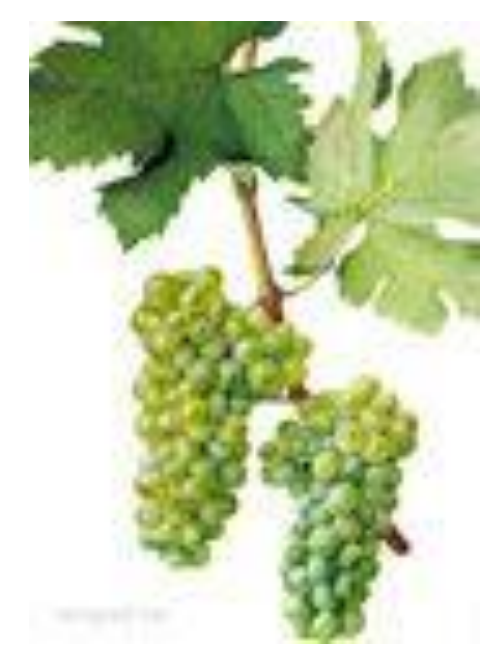

Рис. 3. Ампелоснимок сорта Совиньон белый

Каберне-Совиньон или Лафит - французский сорт. Высокие технологические достоинства сорта обеспечили ему титул «короля» красных вин. Период созревания средне-поздний. Грозди средней плотности. Мякоть сочная. Вкус с пасленовым привкусом. Рост кустов сильный. Коэффициент плодоношения 0,5-0,7; плодоносности - 1,0-1,3. Урожайность 7-8 т/га. Сахаристость сока ягод 17-22 г/100 см³ , титруемая кислотность 7-12 $г / м^{3}$ (рис. 4). 


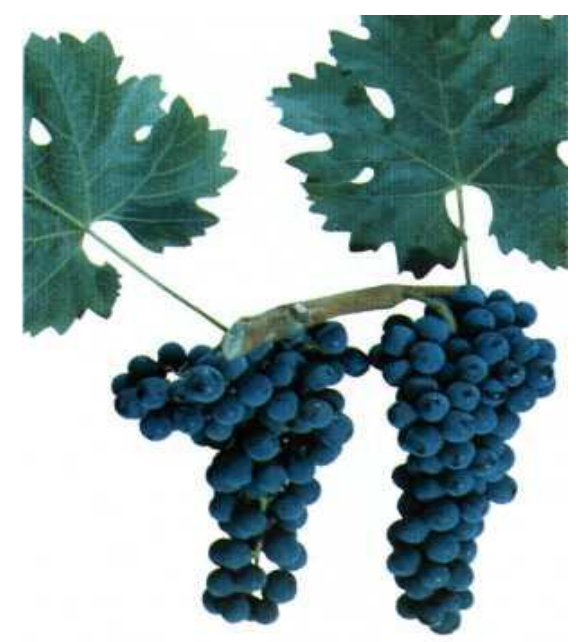

Рис. 4. Ампелоснимок сорта Каберне-Совиньон

Мерло - французский сорт позднего периода созревания. Средняя масса грозди 130 г. Вкус тонкий, гармоничный, с пасленовым привкусом. Сила роста побегов средняя. Вызревание побегов 90-95 \%.

Коэффициент плодоношения 0,6-1,0; плодоносности - 1,2-1,7. Урожайность высокая. Сахаристость сока 9,5-22,0 г/100 см³ при титруемой кислотности 5,2-8,5 г/дм³. Используется для приготовления столовых, крепких или десертных вин очень высокого качества (рис. 5).

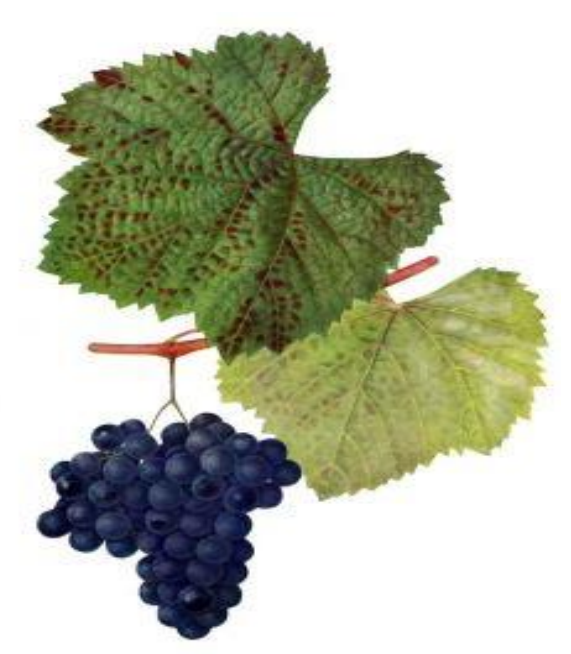

Рис. 5. Ампелоснимок сорта Мерло 
Плодоводство и виноградарство Юга России № 50(02), 2018 г.

Пино нуар или Пино черный. Родина сорта - Франция. Раннего периода созревания. Грозди мелкие или средние (100 г). Ягоды средние, округлые, темно-синие, с восковым налетом. Сила роста кустов средняя. Вызревание побегов 85-90 \%. Плодоносных побегов 80-90 \%. Коэффициент плодоношения 0,9 и плодоносности - 1,7. Урожайность в пределах 5-9 т/га. Сахаристость сока ягод 17-23 г/100 см³ при титруемой кислотности 6-10 г/дм³ (рис. 6).

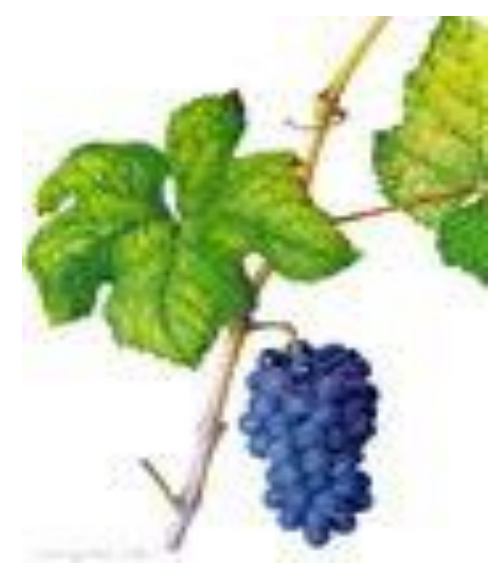

Рис. 6. Ампелоснимок сорта Пино нуар

Кусты сформированы по типу Гюйо со схемой посадки 2,0 х 1,5 м (рис. 7).

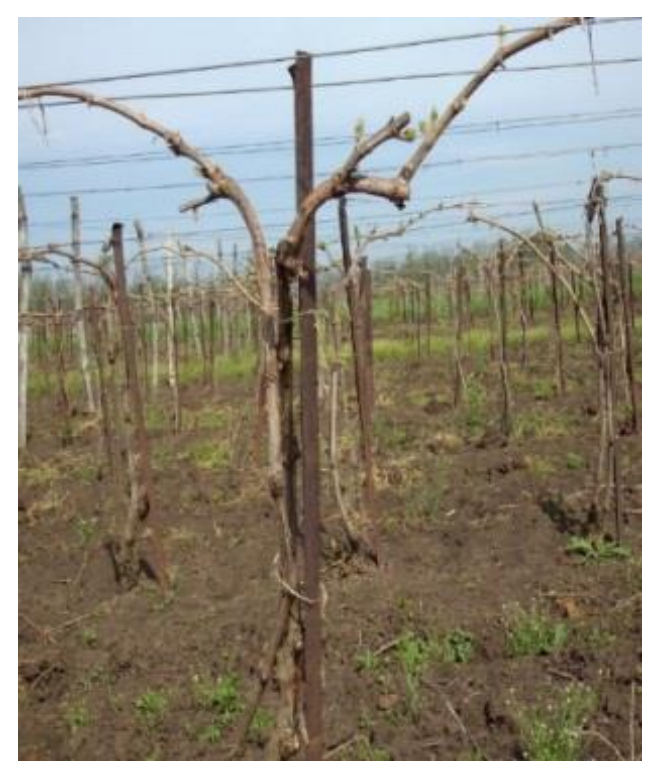

Рис. 7. Форма куста - Гюйо 
Плодоводство и виноградарство Юга России № 50(02), 2018 г.

В работе использовалась общепринятая методика и методические разработки по виноградарству ВНИИВиВ им. Я.И. Потапенко под редакцией Е.И. Захаровой [9].

Обсуждение результатов. Биологические показатели плодоношения глазков в среднем по каждому исследуемому сорту винограда представлены в табл. 1.

Исследования показали, что в группе сортов с белой окраской ягод были выявлены более высокие показатели коэффициентов плодоношения и плодоносности глазков у сорта Рислинг, являющего контролем для этой группы, и составили соответственно 1,63 и 1,76.

Таблица 1 - Биологические показатели плодоношения зимующих глазков сортов винограда (среднее за 2014-2016 гг.)

\begin{tabular}{|c|c|c|c|c|c|c|c|}
\hline \multirow[b]{2}{*}{ Сорт } & \multirow[b]{2}{*}{$\mathrm{K}_{1}$} & \multirow[b]{2}{*}{$\mathrm{K}_{2}$} & \multirow[b]{2}{*}{$\mathrm{K}_{\text {п }}$} & \multirow[b]{2}{*}{$\Gamma \%$} & \multirow{2}{*}{ 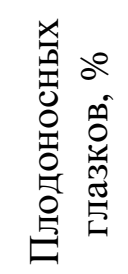 } & \multicolumn{2}{|c|}{ Глазков } \\
\hline & & & & & & $\begin{array}{c}\text { с 1-м } \\
\text { соцветием, } \\
\%\end{array}$ & $\begin{array}{c}\text { с 2-мя } \\
\text { соцветиями, } \\
\%\end{array}$ \\
\hline Рислинг (к) & 1,63 & 1,76 & 1,30 & 22,0 & 92,3 & 29,2 & 70,8 \\
\hline Шардоне & 1,47 & 1,55 & 1,18 & 19,0 & 95,0 & 28,0 & 72,0 \\
\hline Совиньон & 1,21 & 1,50 & 1,03 & 15,0 & 81,0 & 33,0 & 67,0 \\
\hline $\begin{array}{l}\text { Каберне- } \\
\text { Совиньон (к) } \\
\end{array}$ & 1,61 & 1,73 & 1,40 & 13,0 & 93,0 & 26,8 & 73,2 \\
\hline Мерло & 1,61 & 1,83 & 1,50 & 7,0 & 88,2 & 15,8 & 84,2 \\
\hline Пино нуар & 1,38 & 1,53 & 1,16 & 16,0 & 90,0 & 31,0 & 69,0 \\
\hline $\mathrm{HCP}_{05}$ & 0,07 & 0,05 & & & & & \\
\hline
\end{tabular}

У двух других сортов этой группы - Шардоне и Совиньон коэффициенты плодоношения составили 1,47 и 1,21; коэффициенты плодоносности $-1,55$ и 1,50. Гибель глазков оказалась незначительной и составила по сортам от 7 до $22 \%$.

В группе сортов с темной окраской ягод более высокие показатели коэффициентов плодоношения и плодоносности почек зимующих глаз- 
ков наблюдались у сорта Каберне-Совиньон (контроль для этой группы) и у сорта Мерло, соответственно: плодоношения 1,61; плодоносности 1,76 и 1,83 . У сорта Пино нуар коэффициент плодоношения $-1,38$; плодоносности - 1,53.

Выявлены более высокие проценты плодоносных глазков у Рислинга и Шардоне в группе сортов с белой окраской ягод, которые составили соответственно 92,3 и 95,0 \%. В группе сортов с темной окраской ягод более высокие показатели плодоносных глазков отмечены у сортов Каберне-Совиньон и Пино нуар, соответственно 93,0 и 90,0 \%.

Важным показателем для получения высокого урожая винограда является процент глазков с двумя и более эмбриональными (зачаточными) соцветиями. Более высокое значение указанного показателя отмечено у сортов Рислинг и Шардоне - 70,8 и 72,0 \%, а также у сортов Каберне-Совиньон и Мерло -73,2 и 84,2\%.

Таблица 2 - Коэффициенты плодоношения зимующих глазков по ярусам плодового побега, в среднем за 2014-2016 гг.

\begin{tabular}{|l|c|c|c|}
\hline \multirow{2}{*}{\multicolumn{1}{|c|}{ Сорт }} & \multicolumn{3}{|c|}{ Группы глазков по длине плодового побега } \\
\cline { 2 - 4 } & $1-3$ & $4-6$ & $7-10$ \\
\hline Рислинг & 1,03 & 1,66 & 1,97 \\
\hline Шардоне & 1,36 & 1,43 & 1,63 \\
\hline Совиньон & 0,70 & 1,27 & 1,42 \\
\hline $\begin{array}{l}\text { Каберне- } \\
\text { Совиньон }\end{array}$ & 1,72 & 1,50 & 1,60 \\
\hline Мерло & 1,17 & 1,72 & 1,86 \\
\hline Пино нуар & 1,02 & 1,60 & 1,53 \\
\hline
\end{tabular}

Данные табл. 2 свидетельствуют о том, что у исследуемых сортов винограда в условиях предгорной зоны Крымского района Краснодарского края наблюдается разнокачественность по степени закладки эмбриональных соцветий в глазках по длине плодового побега. У большинства сортов в нижней зоне плодового побега (1-3 глазки) коэффици- 
Плодоводство и виноградарство Юга России № 50(02), 2018 г.

енты плодоношения значительно ниже по сравнению со средней (4-6 глазки) и верхней (7-10 глазки) ярусами. Исключение составил сорт Каберне-Совиньон, у которого коэффициенты плодоношения глазков по длине побега различались незначительно.

Ежегодно весной, после распускания почек и появления на вегетирующих побегах соцветий и усиков, на участках каждого исследуемого сорта были проведены агробиологические учеты. На основании их результатов были рассчитаны коэффициенты плодоношения и плодоносности вегетирующих побегов. Данные за три года исследований представлены в табл. 3.

Таблица 3 - Агробиологические показатели плодоношения вегетирующих побегов изучаемых сортов винограда (среднее за 2014-2016 гг.)

\begin{tabular}{|c|c|c|c|c|c|c|}
\hline \multirow{2}{*}{ Copт } & \multicolumn{2}{|c|}{$\begin{array}{c}\text { Нагрузка на куст, } \\
\text { шт. }\end{array}$} & \multirow{2}{*}{$\begin{array}{c}\text { Процент } \\
\text { плодоносных } \\
\text { побегов }\end{array}$} & \multirow{2}{*}{$\begin{array}{c}\text { Количество } \\
\text { соцветий } \\
\text { на куст, шт. }\end{array}$} & \multirow[b]{2}{*}{$\mathrm{K}_{1}$} & \multirow[b]{2}{*}{$\mathrm{K}_{2}$} \\
\hline & $\begin{array}{c}\text { побегов } \\
\text { всего }\end{array}$ & $\begin{array}{l}\text { плодо- } \\
\text { носных }\end{array}$ & & & & \\
\hline Рислинг & 13,6 & 11,5 & 84,6 & 18,0 & 1,32 & 1,56 \\
\hline Совиньон & 11,0 & 10,1 & 91,8 & 15,1 & 1,37 & 1,50 \\
\hline Шардоне & 16,5 & 14,3 & 86,7 & 20,0 & 1,21 & 1,41 \\
\hline $\begin{array}{l}\text { Каберне- } \\
\text { Совиньон }\end{array}$ & 16,2 & 13,9 & 85,8 & 21,3 & 1,31 & 1,53 \\
\hline Мерло & 10,9 & 9,3 & 85,3 & 15,2 & 1,41 & 1,63 \\
\hline $\begin{array}{l}\text { Пино } \\
\text { нуар }\end{array}$ & 13,1 & 12,6 & 96,2 & 18,1 & 1,38 & 1,43 \\
\hline
\end{tabular}

Из табл. 3 следует, что нагрузка виноградных растений вегетирующими побегами (в среднем на куст) на опытных участках исследуемых сортов - от 11 до 16 шт. Количество плодоносных побегов оказалось достаточно высокими - от 85 до $96 \%$.

Для сравнения необходимо отметить, что эмбриональная плодоносность глазков отличалась незначительно от фактической плодоносности 
Плодоводство и виноградарство Юга России № 50(02), 2018 г.

вегетирующих побегов и составила по сортам соответственно: эмбриональная - от 81 до $95 \%$; фактическая - от 85 до $96 \%$.

Коэффициенты плодоношения побегов по сортам несколько отличаются по величине. Более высокие коэффициенты плодоношения отмечены у сортов: Мерло - 1,41; Пино нуар $-1,38$; Совиньон - 1,37. Заметно ниже коэффициенты плодоношения побегов у сортов: Рислинг - 1,32; КабернеСовиньон $-1,31$ и Шардоне $-1,21$. Однако коэффициенты плодоносности побегов были по всем исследуемым сортам высокими и различались незначительно.

Цель всех работ, проводимых на винограднике, - получение высокого урожая хорошего качества. В табл. 4 представлены данные по урожаю винограда в условиях Крымского района.

Средняя масса гроздей винограда варьировала от 83 г у сорта Каберне-Совиньон до 98 г у сорта Совиньон. Исключение составил сорт Мерло, у которого указанный показатель - 132 г.

Таблица 4 - Урожай винограда изучаемых технических сортов (среднее за 2014-2016 гг.)

\begin{tabular}{|l|c|c|c|c|}
\hline \multicolumn{1}{|c|}{ Сорт } & $\begin{array}{c}\text { Масса } \\
\text { грозди, }\end{array}$ & $\begin{array}{c}\text { Урожай } \\
\text { с куста, кг }\end{array}$ & $\%$ & $\begin{array}{c}\text { Урожайность, } \\
\text { т/га }\end{array}$ \\
\hline Рислинг (к) & 95 & 1,7 & 100,0 & 5,61 \\
\hline Совиньон & 98 & 1,5 & 88,2 & 5,26 \\
\hline Шардоне & 95 & 1,9 & 111,8 & 6,27 \\
\hline Каберне-Совиньон & 83 & 1,8 & 105,9 & 5,88 \\
\hline Мерло & 132 & 1,9 & 111,8 & 6,53 \\
\hline Пино нуар & 85 & 1,6 & 94,1 & 5,51 \\
\hline НСР 05 & & 0,08 & & \\
\hline
\end{tabular}

Более высокая урожайность отмечена на участке винограда Мерло, где она составила 6,53 т/га. Несколько ниже этот показатель у сорта Шар- 
доне $-6,27$ т/га. По остальным сортам урожайность составила: Рислинг 5,61; Совиньон - 5,26; Каберне-Совиньон - 5,88; Пино нуар - 5,51 т/га.

В табл. 5 представлены данные по содержанию сахаров и органических кислот в соке ягод у исследуемых сортов винограда.

Таблица 5 - Качественные показатели урожая технических сортов винограда (среднее за 2014-2016 гг.)

\begin{tabular}{|l|c|c|}
\hline \multicolumn{1}{|c|}{ Сорт } & $\begin{array}{c}\text { Содержание сахаров, } \\
\Gamma / 100 \mathrm{~cm}^{3}\end{array}$ & $\begin{array}{c}\text { Tитруемая кислотность, } \\
\Gamma_{\text {дмм }}{ }^{3}\end{array}$ \\
\hline Рислинг (к) & 22,0 & 4,1 \\
\hline Совиньон & 21,2 & 6,3 \\
\hline Шардоне & 21,1 & 10,4 \\
\hline Каберне-Совиньон (к) & 24,0 & 6,6 \\
\hline Мерло & 23,8 & 3,9 \\
\hline Пино нуар & 25,9 & 4,9 \\
\hline \multicolumn{1}{|c|}{$\mathrm{HCP}_{05}$} & 0,2 & 1,3 \\
\hline
\end{tabular}

В условиях предгорной зоны Краснодарского края технические сорта с темной окраской ягод были способны накопить более высокое количество сахаров, по сравнению с сортами с белой окраской ягод. Так, если у Пино нуар, Каберне-Совиньон и Мерло содержание сахаров в соке ягод к моменту уборки урожая винограда было соответственно 25,9; 24,0 и 23,8 г/100 $\mathrm{cm}^{3}$, то у технических сортов с белой окраской ягод массовая концентрация сахаров в соке ягод в этот период составила у сорта Рислинг - 22,0; Совиньон - 21,2; Шардоне - 21,1 г/100 см³.

По содержанию титруемых кислот у группы сортов с белой окраской ягод более высокие показатели были у Шардоне - 10,4 г/дм³. В группе темноокрашенных сортов содержание органических кислот не превышало 6,6 г/дм².

Повышение эффективности сельскохозяйственного производства является одной из наиболее актуальных проблем, успешное решение которой открывает дальнейшие возможности для ускорения темпов его развития и надежного снабжения страны сельскохозяйственной продукцией. 
Плодоводство и виноградарство Юга России № 50(02), 2018 г.

Таблица 6 - Экономическая эффективность возделывания технических сортов винограда в условиях предгорной зоны (среднее за 2014-2016 гг.)

\begin{tabular}{|l|c|c|c|c|c|c|}
\hline \multicolumn{1}{|c|}{ Показатель } & Рислинг & Совиньон & Шардоне & Каберне & Мерло & $\begin{array}{c}\text { Пино } \\
\text { нуар }\end{array}$ \\
\hline Урожайность, т/га & 5,61 & 5,26 & 6,27 & 5,88 & 6,53 & 5,51 \\
\hline $\begin{array}{l}\text { Цена реализации 1 т, } \\
\text { тыс. руб. }\end{array}$ & 20,0 & 20,0 & 20,0 & 25,0 & 25,0 & 20,0 \\
\hline $\begin{array}{l}\text { Стоимость валовой } \\
\text { продукции, тыс. руб. }\end{array}$ & 112,2 & 105,2 & 125,4 & 147,0 & 163,2 & 110,2 \\
\hline $\begin{array}{l}\text { Производственные } \\
\text { затраты, тыс. руб. }\end{array}$ & 88,7 & 87,3 & 91,5 & 92,6 & 97,5 & 88,2 \\
\hline $\begin{array}{l}\text { Себестоимость 1 т., } \\
\text { тыс. руб. }\end{array}$ & 15,8 & 16,6 & 14,6 & 15,7 & 14,9 & 16,0 \\
\hline $\begin{array}{l}\text { Чистый доход, } \\
\text { тыс. руб. }\end{array}$ & 23,5 & 17,9 & 33,9 & 61,0 & 65,7 & 22,0 \\
\hline Рентабельность, \% & 26,4 & 20,5 & 37,0 & 65,8 & 67,3 & 24,9 \\
\hline
\end{tabular}

Из данных табл. 6 следует, что более низкая себестоимость продукции винограда оказалась у сортов Шардоне и Мерло, соответственно 15,6 тыс. руб./т и 14,9 тыс. руб./т.

Более высокие показатели чистого дохода и уровня рентабельности получены у сортов с темной окраской ягод: у Каберне-Совиньон и Мерло чистый доход - 61,0 и 65,7 тыс. руб./га, а уровень рентабельности - 65,8 и 67,3\%. У сортов с белой окраской ягод наибольшие показатели эффективности возделывания у сорта Шардоне: чистый доход 33,9 тыс. руб./га, уровень рентабельности $37,0 \%$.

Bblвodbl. Более высокие коэффициенты плодоношения и плодоносности глазков в группе сортов винограда с белыми ягодами отмечены у сорта Рислинг: $К_{1}-1,63$ и $\mathrm{K}_{2}-1,76$; в группе с черными ягодами - у сорта Мерло: $\mathrm{K}_{1}-1,61$ и $\mathrm{K}_{2}-1,83$; у сорта Каберне-Совиньон: $\mathrm{K}_{1}-1,61$ и $\mathrm{K}_{2}-1,76$.

Коэффициенты плодоношения и плодоносности вегетирующих побегов имели большие значения у сортов Рислинг и Совиньон в группе сортов с белыми ягодами (К $K_{1}-1,32$ и 1,37 ; и $K_{2}-1,50$ и 1,55$)$, а в группе с черными ягодами - у сорта Мерло $\left(\mathrm{K}_{1}-1,41\right.$ и $\left.\mathrm{K}_{2}-1,63\right)$. 
Плодоводство и виноградарство Юга России № 50(02), 2018 г.

Наибольшую урожайность в группе сортов винограда с белыми ягодами показали сорта Рислинг и Шардоне - 5,61 и 6,27 т/га; в группе с темными ягодами - Каберне-Совиньон и Мерло: 5,88 и 6,53 т/га.

Экономические показатели возделывания винограда в группе сортов с белыми ягодами были лучшими у сорта Шардоне (чистый доход составил 33,9 тыс. руб./га, а уровень рентабельности 37,0 \%); в группе с темными ягодами - у сортов Мерло и Каберне-Совиньон, у которых чистый доход составил соответственно 65,7 тыс. руб./га и 61,0 тыс. руб./га, а уровень рентабельности - 67,3 и 65,8\%.

\section{Литература}

1. Матузок, Н.В. Особенности агробиологических показателей некоторых донских аборигенных сортов винограда в условиях Анапо-Таманской зоны виноградарства Краснодарского края / Н.В. Матузок, Л.П. Трошин, М.А. Малтабар [и др.] // Политематический сетевой электронный научный журнал КубГАУ. - Краснодар: КубГАУ, 2015. - №06(110). - C. 1531-1544. - IDA [article ID]: 1101506101. - Режим доступа: http://ej.kubagro.ru/2015/06/pdf/101.pdf, 0,875 у.п.л.

2. Матузок, Н.В. Особенности развития генеративных органов растений винограда сортов разного происхождения в условиях Тамани / Н.В. Матузок, П.П. Радчевский, Т.И. Кузьмина [и др.] // Политематический сетевой электронный научный журнал КубГАУ. - Краснодар: КубГАУ, 2014. - №03(097). - С. 120-137. - IDA [article ID]: 0971403010. - Режим доступа: http://ej.kubagro.ru/2014/03/pdf/10.pdf, 1,125 у.п.л.

3. Banjanin, T.; Rankovic-Vasic, Z. Impact of climate factors on agro biological characteristics of Pinot Noir variety in Trebinje vineyard // Proceedings of the VIIth International Scientific Agriculture Symposium, "Agrosym 2016", 6-9 October 2016, Jahorina, Bosnia and Herzegovina. - 2016. - 116-121.

4. Roychev, V. Comparative ampelographic evaluation of the earliest ripening and very early ripening table vine cultivars // Lozarstvo i Vinarstvo. - 2016. - 64 (1). - S. 11-17.

5. Vujovic, D. S.; Zunic, D. M.; Pejin, B. M.; Popovic-Djordevic, J. B. Ampelographic description of cluster, berry and seed of Merlot cultivar (*Vitis vinifera* L.) and its selected clones // Journal of Agricultural Sciences. - 2016. - 61 (1). - S. 45-55.

6. Матузок, Н.В. Прогнозирование урожая технических сортов винограда с белой окраской ягод на основе изучения эмбриональной плодоносности глазков в условиях Анапо-Таманской зоны Краснодарского края / Н.В. Матузок, С.М. Горлов, П.П. Радчевский, Л.П. Трошин // Политематический сетевой электронный научный журнал м Краснодар: КубГАУ, 2016. - №07(121). - С. 1545-1582. - IDA [article ID]: 1211607094. Режим доступа: http://ej.kubagro.ru/2016/07/pdf/94.pdf, 2,375 у.п.л.

7. Матузок, Н.В. Прогнозирование урожая винограда и установление оптимальной нагрузки кустов при обрезке в глазках по планируемой урожайности на примере ОАО АФ «Южная» / Н.В. Матузок, Л.П. Трошин, С.М. Горлов // Политематический сетевой электронный научный журнал КубГАУ. - Краснодар: КубГАУ, 2016. №02(116). - C. 355-372. - IDA [article ID]: 1161602026. - Режим доступа: http://ej.kubagro.ru/2016/02/pdf/26.pdf, 1,125 у.п.л. 
8. Матузок, Н.В. Оптимизация технологии возделывания винограда на основе использования метода прогнозирования урожайности / Н.В. Матузок, Л.П. Трошин // Политематический сетевой электронный научный журнал КубГАУ. - Краснодар: КубГАУ, 2015. - №01(105). - С. 1000-1034. - IDA [article ID]: 1051501061. - Режим доступа: http://ej.kubagro.ru /2015/01/pdf/61.pdf, 2,188 у.п.л.

9. Захарова, Е.И. Программа и методика агротехнических опытов в виноградарстве / Е.И. Захарова. - Ростов н/Д.,1952. - 68 с.

\section{References}

1. Matuzok, N.V. Osobennosti agrobiologicheskih pokazatelej nekotoryh donskih aborigennyh sortov vinograda $\mathrm{v}$ uslovijah Anapo-Tamanskoj zony vinogradarstva Krasnodarskogo kraja / N.V. Matuzok, L.P. Troshin, M.A. Maltabar [i dr.] // Politematicheskij setevoj jelektronnyj nauchnyj zhurnal KubGAU. - Krasnodar: KubGAU, 2015. - №06(110). - S. 1531-1544. - IDA [article ID]: 1101506101. - Rezhim dostupa: http://ej.kubagro.ru/2015/06/pdf/101.pdf, 0,875 u.p.1.

2. Matuzok, N.V. Osobennosti razvitija generativnyh organov rastenij vinograda sortov raznogo proishozhdenija $\mathrm{v}$ uslovijah Tamani / N.V. Matuzok, P.P. Radchevskij, T.I. Kuz'mina [i dr.] // Politematicheskij setevoj jelektronnyj nauchnyj zhurnal KubGAU. Krasnodar: KubGAU, 2014. - №03(097). - S. 120-137. - IDA [article ID]: 0971403010. Rezhim dostupa: http://ej.kubagro.ru/2014/03/pdf/10.pdf, 1,125 u.p.1.

3. Banjanin, T.; Rankovic-Vasic, Z. Impact of climate factors on agro biological characteristics of Pinot Noir variety in Trebinje vineyard // Proceedings of the VIIth International Scientific Agriculture Symposium, "Agrosym 2016", 6-9 October 2016, Jahorina, Bosnia and Herzegovina. - 2016. - 116-121.

4. Roychev, V. Comparative ampelographic evaluation of the earliest ripening and very early ripening table vine cultivars // Lozarstvo i Vinarstvo. - 2016. - 64 (1). - S. 11-17.

5. Vujovic, D. S.; Zunic, D. M.; Pejin, B. M.; Popovic-Djordevic, J. B. Ampelographic description of cluster, berry and seed of Merlot cultivar (*Vitis vinifera* L.) and its selected clones // Journal of Agricultural Sciences. - 2016. - 61 (1). - S. 45-55.

6. Matuzok, N.V. Prognozirovanie urozhaja tehnicheskih sortov vi-nograda s beloj okraskoj jagod na osnove izuchenija jembrional'noj plodonosnosti glazkov v uslovijah AnapoTamanskoj zony Krasnodarskogo kraja / N.V. Matuzok, S.M. Gorlov, P.P. Radchevskij, L.P. Troshin // Politematicheskij setevoj jelektronnyj nauchnyj zhurnal KubGAU, - Krasnodar: KubGAU, 2016. - №07(121). - S. 1545-1582. - IDA [article ID]: 1211607094. Rezhim dostupa: http://ej.kubagro.ru/2016/07/pdf/94.pdf, 2,375 u.p.1.

7. Matuzok, N.V. Prognozirovanie urozhaja vinograda i ustanovlenie optimal'noj nagruzki kustov pri obrezke v glazkah po planiruemoj urozhajnosti na primere OAO AF «Juzhnaja» / N.V. Matuzok, L.P. Troshin, S.M. Gorlov // Politematicheskij setevoj jelektronnyj nauchnyj zhurnal KubGAU. - Krasnodar: KubGAU, 2016. - №02(116). - S. 355-372 . - IDA [article ID]: 1161602026. - Rezhim dostupa: http://ej.kubagro.ru/2016/02/pdf/26.pdf, 1,125 u.p.l.

8. Matuzok, N.V. Optimizacija tehnologii vozdelyvanija vinograda na osnove ispol'zovanija metoda prognozirovanija urozhajnosti / N.V. Matuzok, L.P. Troshin // Politematicheskij setevoj jelektronnyj nauchnyj zhurnal KubGAU. - Krasnodar: KubGAU, 2015. - №01(105). - S. 1000-1034. - IDA [article ID]: 1051501061. - Rezhim dostupa: http://ej.kubagro.ru /2015/01/pdf/61.pdf, 2,188 u.p.1.

9. Zaharova, E.I. Programma i metodika agrotehnicheskih opytov v vinogradarstve / E.I. Zaharova. - Rostov n/D.,1952. - 68 s. 